JURNAL KETAHANAN NASIONAL

Vol. 26, No. 2, Agustus 2020, Hal 273-292

DOI:http://dx.doi.org/ 10.22146/jkn.56318

ISSN:0853-9340(Print), ISSN:2527-9688(Online)

Online sejak 28 Desember 2015 di :http://jurnal.ugm.ac.id/JKN

VOLUME 26

No. 2, Agustus 2020

Halaman 273-292

\title{
Kerjasama Pengembangan Medium Battle Tank Harimau Sebagai Perwujudan Ketahanan Alutsista Tentara Nasional Indonesia
}

\author{
Febry Triantama \\ Pascasarjana Ilmu Hubungan Internasional, Universitas Indonesia, Jawa Barat \\ Program Studi Ilmu Hubungan Internasional, Universitas Paramadina, DKI Jakarta \\ email: febry.triantama@ui.ac.id
}

Dikirim: 15-05-2020; DiRevisi: 29-07-2020; Diterima:28-08-2020

\begin{abstract}
Anarchic international systems forced countries in the world to ensured their own survival. Countries were competing to increased their power capacity, one of which was implemented through autarky. Indonesia as a country that had bad experiences as a result of its dependence on arms produced by other countries and to achieved national arms resilience was intensively developing its indigenous defense industry. One of them was the development of the medium battle tank Harimau with Turkey.

This article would explain the reasons for Indonesia to developed medium battle tank Harimau using the concept of techno-nationalist impulse and through descriptive analytical methods.

This article argued that Indonesia's decision to developed a medium battle tank part of its strategies to achieved national Arms resilience which based on the pursuit of power, pursuit of wealth and pursuit of prestige.

Keywords: Defense Industry; Medium Battle Tank Harimau; Techno-Nationalist Impulse; National Arms Resilience.

ABSTRAK

Sistem internasional yang anarki memaksa negara-negara di dunia untuk memastikan kelangsungan hidupnya sendiri. Negara-negara berlomba-lomba untuk meningkatkan kapasitas power mereka, salah satunya diimplementasikan melalui kemandirian pertahanan. Indonesia sebagai negara yang telah memiliki pengalaman buruk akibat dari ketergantungan terhadap alutsista yang diproduksi negara lain serta berupaya mewujudkan ketahanan alutsista tengah gencar melakukan pengembangan industri pertahanannya. Salah satunya adalah pengembangan medium battle tank Harimau bersama dengan Turki.

Artikel ini akan membedah alasan Indonesia melakukan pengembangan medium battle tank Harimau dengan Turki menggunakan konsep techno-nationalist impulse dan melalui metode deskriptif analitis.

Artikel ini menyatakan bahwasanya keputusan Indonesia melakukan pengembangan medium battle tank merupakan strategi perwujudan ketahanan alutsista dan didasarkan pada pursuit of power, pursuit of wealth serta pursuit of prestige.
\end{abstract}

Kata Kunci: Industri Pertahanan; Medium Battle Tank Harimau; Techno-Nationalist Impulse; Ketahanan Alutsista. 


\section{PENGANTAR}

Dalam sistem internasional yang anarki setiap negara akan memastikan diri memiliki kepemilikan power yang lebih kuat dari negara lainnya (Mearsheimer, 2001). Kepemilikan power suatu negara selain dilihat dari jumlah alutsista yang dimiliki juga dapat dilihat dari kemandirian pertahanannya (Bitzinger, 2003). Ketika suatu negara tidak mampu mencapai kemandirian pertahanan atau menggantungkan diri pada senjata yang diproduksi negara lain maka negara tersebut belum bisa dikatakan sebagai negara yang kuat. Hal ini dikarenakan negara tersebut akan terus berada dibawah bayang-bayang pengaruh dan power negara produsen senjata mereka (Krause, 1991; Neuman, 2010). Salah satu bentuk penggunaan pengaruh negaranegara produsen senjata adalah dengan pemberian embargo (Rosh, 1990; Neuman, 2010). Negara-negara produsen senjata kerap mempergunakan ancaman embargo untuk mempengaruhi kebijakan suatu negara (Neuman, 2010).

Merujuk pada argumentasi teoretik tersebut, Indonesia bisa dikatakan menjadi salah satu contoh bagaimana pengaruh negara-negara produsen senjata terhadap kapasitas militer. Jika menilik pada fakta sejarah, Indonesia pernah memiliki kekuatan militer yang disegani di kawasan (Tempo. co, 2014). Hal ini dikarenakan Indonesia pernah mengoperasikan alat utama sistem persenjataan (Alutsista) yang canggih pada dekade 1960-an. Kecanggihan alutsista yang pernah dioperasikan Indonesia pada saat itu melebihi alutsista milik negara-negara lain di kawasan Asia Tenggara. Sebagai contohnya adalah Indonesia mengoperasikan kapal perang kelas penjelajah, yang dikenal dengan KRI Irian 201 (Tempo.co, 2014). Selain itu Indonesia pada waktu yang bersamaan juga mengoperasikan 12 kapal selam kelas Whiskey (Tempo.co, 2014). Namun kejayaan militer Indonesia ini berangsur-angsur pudar.

Pudarnya kejayaan militer Indonesia turut dipengaruhi oleh kebijakan Amerika Serikat beserta negara-negara sekutunya seperti Inggris untuk mengembargo Indonesia. Embargo membuat pertahanan Indonesia semakin lemah. Sebagian jet tempur F-16 yang belum lama dibeli oleh Indonesia harus grounded karena tidak adanya pasokan suku cadang untuk mengganti suku cadang yang rusak atau harus diganti (Anggi dan Resty, 2016). Selain itu, melalui embargo tersebut Indonesia juga tidak diperbolehkan untuk menggunakan alutsista yang berasal dari Amerika Serikat dan sekutu-sekutunya (Firmansyah, 2018). Hal ini bukan hanya sangat merugikan bagi Indonesia, melainkan juga membahayakan survivalitas Indonesia sekaligus menunjukkan ketahanan nasional Indonesia khususnya ketahanan alutsista masih lemah. Sebagaimana diketahui ketahanan nasional adalah sebuah konsepsi yang menekankan pada pembangunan nasional yang berorientasi terhadap pencapaian tujuan maupun cita-cita bangsa. Ketahnan nasional juga menekankan pada kemampuan bangsa Indonesia menghadapi segala bentuk ancaman, termasuk ancaman yang berpotensi mengancam dan membahayakan integritas serta survivalitas bangsa (Taufik, 2013). Oleh karena itu perwujudan ketahanan nasional tidak bisa dilepaskan dari aspek pertahanan dan keamanan, terutama ketahanan alutsista.

Didasarkan pada pengalaman sejarah menjadi korban embargo Amerika Serikat dan sekutu-sekutunya serta sebagai bentuk perwujudan ketahanaAlutsista maka Pemerintah Indonesia mulai menaruh perhatian yang lebih 
besar pada industri pertahanan. Hal ini bisa terlihat melalui kerjasama industri pertahanan yang gencar dilakukan. Kerjasama industri pertahanan yang dilakukan oleh Indonesia dengan berbagai negara - Korea Selatan, Tiongkok, Turki - ditujukan untuk menciptakan kemandirian pertahanan. Melalui kerjasama industri pertahanan Indonesia berupaya untuk mampu menciptakan alutsista secara mandiri dan terbebas dari ancaman embargo yang secara tidak langsung erat kaitannya dengan ketahanan nasional (Sudarmanto dan Sudibyakto, 2011; Kementerian Pertahanan, 2014). Adapaun yang menjadi salah satu bentuk kerjasama industri pertahanan Indonesia adalah kerjasama pengembangan Medium battle tank dengan Turki.

Kerjasama pengembangan Medium battle tank antara Indonesia dan Turki dimulai sejak penandatanganan MoU antara PT. Pindad dan FNSS. PT. Pindad dan FNSS merupakan dua BUMN yang ditunjuk Indonesia maupun Turki untuk melakukan pengembangan bersama Medium battle tank. Keduanya menandatangani MoU pada tahun 2014, bersamaan dengan perhelatan Indo Defence Expo \& Forum 2014 (Stefani, 2014; Tempo. co, 2014). Kerjasama pengembangan Medium battle tank ini kemudian berhasil menghasilkan dua purwarupa yang diperkenalkan pada tahun 2017 di International Defence Industry Fair (IDEF) (Rahmat \& Cranny-Evans, 2019). Selang satu tahun kemudian, pada tahun 2018 Medium battle tank Harimau resmi dinyatakan lulus uji sertifikasi Tentara Nasional Indonesia (TNI) (Siddiq, 2018). Setelah lulus uji sertifikasi ini maka medium tank Harimau resmi bisa menjadi bagian dari alutsista TNI dan mulai memasuki fase produksi massal.

Menyadari bahwasanya pada saat ini Indonesia sedang gencar melakukan kerjasama industri pertahanan dengan berbagai negara di dunia, telah terdapat beberapa penelitian terdahulu yang membahas isu ini. Penelitianpenelitian yang telah dilakukan sebelumnya dapat dikategorikan menjadi tiga kategori, yakni: (1) Pertahanan, (2) Politik Domestik dan (3) Ekonomi-Politik. Selain tiga kategori tersebut penelitian mengenai kerjasama industri pertahanan juga banyak dilakukan dalam bentuk argumentative papers.

Penelitian yang termasuk dalam kategori pertahanan secara umum menggambarkan bahwa kerjasama industri pertahanan didasarkan atas pertimbangan dan bertujuan strategis / pertahanan. Pertimbangan dan tujuan strategis kerjasama industri pertahanan yang digambarkan oleh penelitian yang ada di antaranya adalah sebagai strategi diplomasi pertahanan (Amrullah, 2016) (Sulaiman, 2016), difusi militer (Dzikri, 2016), transformasi pertahanan (Luerdi dan Marisa, 2018) serta modernisasi persenjataan (Bitzinger, 2010). Oleh karena itu dapat disimpulkan bahwasanya kerjama industri pertahanan maupun pengembangan senjata yang dilakukan Indonesia merupakan bentuk diplomasi pertahanan, dengan harapan dapat membantu proses reformasi serta transformasi pertahanan. Namun hal ini tidak ada kaitannya dengan perlombaan senjata di Asia Tenggara.

Sedangkan penelitian-penelitian terdahulu mengenai industri pertahanan dalam kategori ekonomi-politik melihat kerjasama industri pertahanan pada akhirnya akan menimbulkan pembagian kelas-kelas industri pertahanan (Armandha, Datumaya dan Sumari, 2015). Selain itu, negara-negara juga memandang bahwasanya kerjasama industri pertahanan dan pengembangan senjata melalui mekanisme offset dapat mendorong terciptanya pertumbuhan ekonomi 
(Bitzinger, 2011). Namun impian untuk memperoleh pertumbuhan ekonomi melalui kerjasama industri pertahanan harus terlebih dahulu melalui hambatan berupa upaya mempertahankan hegemoni negara-negara maju.

Penelitian terdahulu juga ada yang membahas mengenai pengaruh politik domestik dalam penentuan pembelian atau pengadaan senjata Indonesia. Penelitian dalam kategori ini menggunakan perspektif historical institusionalism (Raymond, 2017). Penelitian tersebut menyatakan bahwa pembelian senjata di angkatan laut yang secara kuantitatif tidak sebanding dengan kebutuhan dipengaruhi oleh kondisi domestik Indonesia. Dominasi serta kedekatan elit maupun purnawiran angkatan darat di Indonesia menyebabkan pembelian alutsista didominasi oleh alutsista untuk kebutuhan angkatan darat.

Selain penelitian-penelitian dengan kerangka teoretik yang mapan dalam tiga kategori tersebut, terdapat penelitianpenelitian lainnya yang dikategorikan sebagai argumentative papers. Mayoritas Argumentative papers menyajikan penelitiannya untuk melihat kepentingan nasional. Kepentingan nasional yang dimaksudkan adalah kepentingan ekonomi dan pertahanan. Motif atau kepentingan ekonomi tersebut tentunya adalah mendorong pertumbuhan ekonomi (Salsabiela, 2016). Sedangkan upaya mencapai kemandirian pertahanan (Al-fadhat dan Effendi, 2019) dan capacity building (Collin, 2015) merupakan kepentingan pertahanan negara dalam melakukan kerjasama industri pertahanan. Terdapat pula argumentative papers yang menggabungkan dua jenis kepentingan nasional suatu negara sebagai pendorng kerjasama industri pertahanan (Bitzinger, 2013). Selain argumentative papers yang pembahasannya erat berkaitan dengan kepentingan nasional, terdapat pula argumentative paper yang mengevaluasi efektifitas kerjasama industri pertahanan (Prasetyo dan Salim, 2017) dan melihatnya sebagai bentuk diplomasi (Ball, 2010).

Melalui penelitian-penelitian terdahulu dapat disimpulkan bahwasanya kerjasama industri pertahanan dan pengembangan persenjataan selain sebagai sarana diplomasi pertahanan juga menyiratkan kepentingankepentingan nasional Indonesia. Namun dari berbagai penelitian yang telah dilakukan masih sangat minim penelitian yang membahas mengapa Indonesia memilih untuk bekerjasama dengan Turki dalam pengembangan medium battle tank Harimau. Kerjasama ini sesungguhnya menjadi sangat menarik untuk diteliti lebih lanjut mengingat jika merujuk Stockholm International Peace Research Institute (SIPRI), sejak tahun 1999 Indonesia tidak pernah melakukan pembelian senjata dari Turki (Wiezeman, 2019). Anomali lainnya juga dapat ditemukan dalam aspek kesesuaian terhadap ancaman. Jika merujuk pada Buku Putih Pertahanan Indonesia semenjak edisi kedua (2008) hingga edisi keempat (2015) ancaman Indonesia berada di wilayah laut serta ancaman nontradisional. Pengembangan Medium battle tank harimau tentunya tidak sesuai dengan persepsi ancaman yang ada (Kementerian Pertahanan, 2008, 2014, 2015). Penelitian ini akan mencoba mengisi research gap tersebut dengan membahas mengapa Indonesia memilih melakukan kerjasama industri pertahanan dengan Turki dalam pengembangan medium battle tank menggunakan konsep Technonationalist Impulse.

Techno-nationalist impulse merupakan konsep yang dikemukakan pertama kali 
oleh Robert B Reich, seorang ekonom Amerika Serikat pada tahun 1987. Reich pada mulanya memperkenalkan Technonationalist impulse sebagai suatu konsep ekonomi dan tidak berhubungan dengan militer atau pertahanan. Reich menyatakan bahwa penguasaan teknologi oleh suatu negara merupakan aspek yang menentukan kesejahteraan negara tersebut (Reich, 1987). Bahkan lebih jauh Reich menyatakan bahwa keunggulan teknologi yang dimiliki suatu negara dapat menjadikan negara tersebut menguasai ekonomi dunia (Reich, 1987). David Edgerton kemudian menyampaikan argumen yang serupa, menurutnya upaya penguasaan teknologi secara mandiri oleh suatu negara didorong oleh motivasi untuk menempatkan dirinya pada posisi tertentu dalam persaingan ekonomi internasional (Edgerton, 2007).

Konsep Techno-nationalist impulse yang pada mulanya digunakan pada aspek ekonomi ini kemudian diadopsi kedalam aspek pertahanan oleh pemikiran beberapa tokoh seperti Christopher Hughes, Richard Samuels, Samm Tyroler-Cooper dan Alison Peet serta Richard Bitzinger. Konsep techno-nationalist impulse digunakan untuk menganalisa alasan suatu negara melakukan pengembangan industri pertahanan dan alutsista nasionalnya. Samuels menyatakan bahwa suatu negara melakukan pengembangan kapasitas industri pertahanan semata-mata demi memperoleh kemandirian teknologi persenjataan untuk mendukung pertahanan nasional (Lie dan Samuels, 1995). Hughes kemudian mengutarakan bahwasanya techno-nationalist impulse mendorong negara-negara untuk memperoleh independensi teknologi militer dan persenjataan untuk memaksimalkan kepentingan strategis negara (Hughes, 2011). Tyroler-Cooper dan Peet turut mengadopsi konsep techno-nationalist impulse ke aspek pertahanan dan militer. Menurut keduanya techno-nationalist impulse ditandai oleh komitmen negara untuk mengembangkan kemampuan industri pertahanan nasional untuk menciptakan kemandirian pertahanan (Tyroler-Cooper dan Peet, 2011).

Jika melihat berbagai definisi konseptual tersebut maka ketika suatu negara maka dapat disimpulkan bahwasanya techno-nationalist impulse tidak bisa dipisahkan dari visi negara menciptakan kemandirian industi pertahanan dan persenjataan atau autarky. Selain itu techno-nationalist impulse juga tidak bisa dipisahkan dari keinginan negara meningkatkan kekuatan militer (pursuit of power). Logika yang dipergunakan adalah ketika suatu negara mampu menguasai teknologi persenjataan yang lebih modern dibandingkan negara lain maka akumulasi power negara tersebut juga akan naik.

Sedangkan Richard Bitzinger pada tahun 2015 memberikan pemahaman lebih luas mengenai keterkaitan techno-nationalist impulse dengan kebijakan pengembangan industri pertahanan suatu negara. Bitzinger menyatakan bahwa techno-nationalist impulse yang mempengaruhi keputusan negara untuk melakukan pengambangan industri pertahanan nasional tidak hanya dikarenakan motif ekonomi atau power seperti yang telah disebutkan sebelumnya. Techno-nationalist impulse sebagai pendorong keputusan negara melakukan pengembangan industri pertahanan dipengaruhi oleh motif pengakumulasian power (pursuit of power), kekayaan (pursuit of wealth) serta meningkatkan prestige dari suatu negara (pursuit of prestige) (Bitzinger, 2015; Bağc1 dan Kurç, 2017).

Melalui pemaparan Bitzinger dapat disimpulkan bahwasanya ketika suatu negara 
memilih untuk melakukan pengembangan industri pertahanan maka ketiga motif tersebut saling melengkapi satu sama lain. Negara menyadari dengan melakukan pengembangan industri pertahanan maka kepentingan strategis seperti akumulasi power dan keamanan logistik senjata akan terjamin (pursuit of power). Selain itu negara juga memahami bahwa dengan melakukan pengembangan industri pertahanan berpotensi membawa keuntungan ekonomi bagi negara tersebut. Hal ini dikarenakan industri pertahanan yang kuat akan menyerap tenaga kerja serta meningkatkan kualitas tenaga kerja itu sendiri. Selain itu terbukanya peluang ekspor juga menjadikan negara memperoleh keuntungan ekonomi lainnya (pursuit of wealth). Ketika suatu negara telah memiliki keunggulan teknologi dari negara-negara lain di kawasan maupun dunia karena mampu memproduksi senjata maka posisi negara tersebut akan berada pada struktur sosial yang lebih tinggi (pursuit of prestige).

Penjelasan Bitzinger mengenai keberadaan techno-nationalist impulse sebagai pendorong pengembangan industri pertahanan yang kemudian akan digunakan dalam penelitian ini. Melalui tiga motif technonationalist impulse pengembangan industri pertahanan Bitzinger yaitu pursuit of power, wealth dan prestige ini alasan Indonesia memilih melakukan kerjasama pengembangan medium tank dengan Turki dapat dijelaskan.

Adapun jenis penelitian yang dipakai oleh peneliti adalah jenis deskriptif analitis, yaitu suatu metode penelitian dengan mengungkapkan masalah yang ada kemudian mengolah data, menganalisis, meneliti dan menginterprestasikan serta membuat kesimpulan pembahasannya disusun secara sistematis sehingga masalah yang ada dapat dipahami (Sugiyono, 2009). Adapun teknik pengumpulan data yang digunakan dalam penelitian ini adalah dengan menggunakan studi kepustakaan. Dalam artian peneliti mengumpulkan sejumlah data dan kemudian melakukan analisis pada data-data tersebut dan diklasifikasi pada bagian-bagian spesifik pada penelitian ini. Selanjutnya peneliti akan melakukan analisis data yang sesuai untuk menjawab rumusan masalah dengan menggunakan kerangka pemikiran dan menuliskan kesimpulan.

\section{PEMBAHASAN}

Kondisi Ketahanan Alutsista Dan Kerjasama Industri Pertahanan Indonesia - Turki

Sebagaimana yang telah disesbutkan sebelumya bahwa Indonesia memiliki sejarah menyandang status negara dengan kekuatan militer yang disegani (Tempo.co, 2014). Indonesia ketika itu memiliki alutsita dengan teknologi yang canggih serta menghadirkan daya gentar yang tinggi. Namun kondisi tersebut berbanding terbalik dengan kondisi militer Indonesia saat ini. Indonesia pada saat ini dianggap berbagai pihak tidak memiliki kekuatan militer yang mumpuni. Indonesia sebagai negara dengan luas wilayah terbesar di Asia Tenggara bahkan dianggap tidak lebih kuat dari Singapura. Indonesia tidak memiliki alutsista yang cukup memberikan daya gentar kepada negara-negara lain.

Argumentasi yang menyatakan Indonesia tidak lagi memiliki daya gentar didasarkan pada kondisi alutsista yang dimiliki Indonesia. Alutsista yang dimiliki Indonesia pada saat ini memang didominasi oleh alutsita yang sudah akan memasuki usia pensiun serta tertinggal secara teknologi (Tempo. co, 2014). Ketertinggalan teknologi maupun 
kapabilitas alutsista Indonesia ini akan terlihat di ketiga matra TNI. Pada matra udara, sebagai contohnya adalah jet tempur F-5 E/F milik Indonesia yang baru saja dipensiunkan pada tahun 2017. Kemampuan F-5 E/F ini tentunya kalah jika disandingkan dengan jet tempur milik negara tetangga, seperti Singapura dengan F-16 Blok 52 dan Australia dengan F/A-18F Super Hornet. Bahkan kedua negara tersebut juga menjadi bagian dari pengembangan F-35 Joint Strike Fighter. Pada matra laut, Indonesia juga menunjukkan ketertinggalan dalam hal kapabilitas alutsista yang dimiliki. Indonesia pada saat ini masih mengandalkan kapal perang frigate kelas Van Speijk yang diproduksi sejak tahun 1960-an (Santosa, n.d.). Hal serupa juga terlihat pada matra darat. Salah satu alutsista uzur yang masih dipergunakan TNI AD adalah alutsista kavaleri yakni tank kelas ringan AMX-13 yang mulai beroperasi semenjak tahun 1960-an (Matanasi, 2018).

Menyadari hal tersebut Pemerintah Indonesia tepatnya pada era kepemimpinan Presiden Susilo Bambang Yudhoyono mencanangkan percepatan modernisasi alutsista Indonesia. Sebagai bentuk implementasi dari percepatan modernisasi alutsista Indonesia adalah program Minimum Essential Forces (MEF) dan kelahiran UU No. 16 Tahun 2012 Tentang Industri Pertahanan. MEF merupakan suatu rencana strategis Indonesia agar dapat mencapai postur kekuatan minimal pada tahun 2024. Sedangkan melalui kehadiran UU Industri Pertahanan, maka dapat dipahami bahwasanya modernisasi alutsista yang Indonesia lakukan harus juga memperhatikan pemberdayaan industri pertahanan dalam negeri, baik BUMN maupun swasta. Sesuai dengan amanat UU Industri Pertahanan maka setiap pembelian alutsista
Indonesia wajib melalui skema offset maupun transfer of technology. Kedua program ini dilakukan demi mencapai kondisi TNI yang kuat dan kemandirian pertahanan Indonesia.

Salah satu program peningkatan kapasitas industri pertahanan dalam negeri dan pengembangan alutsista secara mandiri oleh Indonesia adalah melalui kerjasama dengan Turki. Kerjasama industri pertahanan antara Indonesia dengan Turki telah disepakati bahkan sebelum UU Industri Pertahanan disahkan, yakni pada tahun 2010. Ketika itu Presiden Susilo Bambang Yudhoyono berkunjung ke Ankara untuk menandatangani MoU kerjasama industri pertahanan kedua negara (Kementerian Pertahanan, 2015; Luerdi dan Marisa, 2018). MoU ini kemudian diratifikasi oleh Dewan Perwakilan Rakyat (DPR) pada tahun 2014 (Luerdi dan Marisa, 2018). Melalui MoU ini, Indonesia dan Turki melakukan kerjsama-kersajama dalam aspek industri pertahanan (Amrullah, 2016).

Salah satu bentuk kerjasama industri pertahanan antara Indonesia dan Turki adalah pengembangan medium battle tank Harimau. Kerjasama Pengembangan Medium battle tank antara Indonesia dan Turki dimulai sejak penandatanganan MoU antara PT. Pindad dan FNSS. PT. Pindad dan FNSS merupakan dua BUMN yang ditunjuk Indonesia maupun Turki untuk melakukan pengembangan bersama medium battle tank. Keduanya menandatangani MoU pada tahun 2014, bersamaan dengan perhelatan Indo Defence Expo \& Forum 2014 (Stefani, 2014; Tempo. co, 2014). Dalam prosesnya pengembangan medium battle tank Harimau akan melewati tiga tahap (Wulandari, 2017; Pindad, 2016). Tahap pertama adalah tahap pembuatan desain dari medium battle tank Harimau. Proses pembuatan desain yang dilakukan bersama 
antara PT. Pindad dan FNSS ini menghasilkan desain medium battle tank Harimau yang diperkenalkan pada pameran Indo Defence Expo dan Forum 2016 (Badan Riset dan Inovasi Nasional, 2016; Pindad, 2016).

Tahap kedua dalam pengembangan medium battle tank Harimau adalah tahap pembuatan prototype. Tahap pembuatan prototype ini kemudian menghasilkan satu unit prototype yang diperkenalkan pada tahun 2017. Prototype pertama yang berhasil diproduksi ini diperkenalkan pada perhelatan International Defense Industry Fair ke-13 pada tahun 2017 (Yildirim, 2017). Prototype medium battle tank Harimau ini kemudian baru diperkenalkan di Indonesia pada momen peringatan hari TNI ke-72 pada tahun 2017. Prototype medium battle tank Harimau ketika itu ikut dalam defile alutsista TNI (Pindad, 2017). Prototype medium battle tank Harimau kemudian menjalani serangkaian proses uji coba di Indonesia. Setelah melalui serangkaian proses uji coba, medium battle tank Harimau dinyatakan lulus sertifikasi pada tahun 2018 (Siddiq, 2018; Pindad, 2018). Oleh karena itu medium battle tank Harimau siap masuk tahap ketiga yakni tahap produksi (Siddiq, 2018).

\section{Pursuit of Power}

Ketika suatu negara memutuskan untuk melakukan pengembangan alutsistta secara mandiri maka hal tersebut tidak bisa terlepas dari keinginan negara tersebut meningkatkan kapasitas power mereka (pursuit of power). Tidak terkecuali bagi Indonesia sebagai negara yang tengah gencar melakukan peningkatan kapasitas industri pertahan dalam negeri melalui pengembangan alutsista, salah satunya adalah medium battle tank Harimau. Setidaknya terdapat dua hal yang Pemerintah Indonesia akan tercapai ketika program pengembangan medium battle tank Harimau terlaksana. Pertama, kapasitas pertahanan atau akumulasi power Indonesia akan meningkat seiring kehadiran medium battle tank. Kedua, keamanan logistik militer atau pertahanan.

Medium battle tank Harimau merupakan salah satu medium battle tank terbaru dan terbaik di dunia pada saat ini. Hal ini dikarenakan sebagai medium battle tank yang paling baru dikembangkan, maka medium battle tank Harimau telah dibekali teknologi modern. Berdasarkan spesifikasi resmi yang dirilis oleh PT. Pindad dan FNSS maka diketahui bahwa medium battle tank Harimau telah dibekali kemampuan proteksi ledakan level STANAG 4 dan dapat ditingkatkan hingga STANAG 5 (FNSS, 2018). Kemampuan proteksi STANAG 4 yang saat ini diimplementasikan memungkinkan medium battle tank Harimau bertahan dari serangan peluru berkaliber $14.5 \times 114 \mathrm{~mm}$ yang ditembakan dari jarak 200 meter dengan kecepatan 911 m/detik (Armor Specs, 2020). Selain itu medium battle tank Harimau juga tidak hancur oleh ranjau yang berhulu ledak $10 \mathrm{~kg}$ serta bertahan dari serangan artileri berkaliber 155 mm (Armor Specs, 2020; Ramadhan, 2018).

Kecanggihan dan kehebatan medium battle tank Harimau juga semakin baik dengan kehadiran sistem perlindungan diri aktif(APS) PULAT (FNSS, 2019). APS PULAT sendiri merupakan modul yang berisi radar yang akan merasakan dan mendeteksi rudal atau proyektil yang mendekat untuk kemudian dihancurkan sebelum mengenai tank (FNSS, 2019). Penggunaan APS PULAT ini akan meningkatkan kemampuan medium battle tank Harimau dalam pertempuran kota, yang dalam beberapa tahun ini mendominasi. Tingkat proteksi yang tinggi pada medium 
battle tank Harimau ini meminimalisir resiko cedera serta kematian kru yang berada di dalamnya. Tingkat proteksi yang ditawarkan oleh medium battle tank Harimau ini jauh mengungguli kemampuan tank ringan AMX13 maupun Scorpion dan bahkan setara dengan kemampuan main battle tank (MBT) Leopard 2 milik TNI AD namun dengan bobot yang jauh lebih ringan.

Selain kemampuan proteksi medium battle tank Harimau yang sangat baik, keunggulan lainnya adalah penyematan teknologi-teknologi lain seperti turret CMI 3105 varian terbaru yang memiliki bobot lebih ringan dan teknologi paling canggih. Selain itu melalui penggunaan turret CMI 3105 dan meriam kaliber $105 \mathrm{~mm}$ terbaru ini mampu menembak target sejauh $10 \mathrm{~km}$ (FNSS, 2018). Medium battle tank Harimau ini juga menggunakan sistem pengisian ulang meriam otomatis sehingga memungkinkan prosesnya terjadi secara lebih cepat dan memaksimalkan serangan. Selain itu, melalui keberadaan hunter killer system, medium battle tank Harimau dapat memasukkan target ke sebuah sistem untuk dilakukan penembakan secara otomatis dan juga menentukan senjata yang paling tepat digunakan (Siddiq, 2018).

Kemampuan mobilitas yang dihadirkan oleh medium battle tank Harimau juga menjadi satu bentuk keunggulan. Medium battle tank Harimau mampu bergerak dengan sangat lincah untuk ukuran medium battle tank. Berdasarkan spesifikasi teknis pada saat pengembangan dan dikonfirmasi melalui serangkaian uji coba medium battle tank Harimau mampu melaju hingga kecepatan maksimal 70 km/ jam (FNSS, 2018). Selain itu medium battle tank Harimau juga mampu bergerak dengan stabil dan lincah di medan-medan ekstrem seperti pantai maupun hutan (Ikhsanudin,
2018; Kompas.com, 2018). Melalui pengujian yang dilakukan diketahui bahwasanya medium battle tank Harimau mampu bergerak di medan yang memiliki kemiringan mencapai $30^{\circ}$ dan medan menanjak setinggi $60^{\circ}$ (FNSS, 2018). Kemampuan mobilitas yang dimiliki medium battle tank Harimau ini jauh lebih baik dibandingkan dengan MBT Leopard 2 milik Indonesia. MBT Leopard 2 milik Indonesia kesulitan bergerak dengan lincah mengingat bobotnya yang mencapai 65 ton (Fikri, 2018). Selain itu, kontur geografis Indonesia akan menyulitkan mobilitas MBT Leopard 2, lain halnya dengan medium battle tank Harimau (Mutakin, 2017). Hal ini tentunya memungkinkan gelar pasukan tank Harimau lebih mudah dilakukan dan mampu mengamankan wilayah Indonesia secara lebih optimal.

Selain meningkatkan akumulasi power Indonesia melalui keunggulan teknologi dan kemampuan mobilitas, pengembangan medium battle tank Harimau juga memberikan keamanan logistik pertahanan bagi Indonesia. Jika sebelumnya Indonesia menggantungkan kekuatan militer khususnya pada segmen battle tank ke industri-industri persenjataan luar negeri. Terdapat tiga negara yang menjadi pemasok alutsista segmen battle tank, yakni Perancis, Inggris dan Jerman. Melalui kehadiran medium battle tank Harimau, Indonesia secara gradual mampu melepaskan diri dari ketergantungan dan pengaruh negaranegara tersebut. Medium battle tank Harimau pada saat ini telah menggunakan berbagai komponen dalam negeri. Berdasarkan rilis resmi PT. Pindad dapat diketahu bahwasanya 70\% komponen medium battle tank Harimau berasal dari dalam negeri (Fikri, 2018). PT. Pindad melalui direktur utamanya juga menyatakan bahwa Indonesia telah 
menguasai kemampuan mengembangan dan memproduksi battle tank secara penuh (Fikri, 2018).

Selain itu, didorong oleh keberhasilan mengembangkan medium battle tank Harimau, PT. Pindad juga semakin gencar meningkatkan kapasitas produksinya. Peningkatan kapasitas produksi dimaksudkan untuk semakin meningkatkan kandungan produk dalam negeri di medium battle tank Harimau. Salah satu contohnya adalah kini Pindad telah mulai menyiapkan lini produksi untuk turret dan Remote Controlled Weapon Station (RCWS) (Pindad, 2020). Menurut Menteri Pertahanan Indonesia periode 2014 - 2019, Ryamizard Ryacudu, Pengembangan medium battle tank Harimau dan turret merupakan salah satu wujud bela negara dan menjaga eksistensi Indonesia. Menurut Ryamizard, dalam zaman globalisasi, negara yang kuat pasti akan menjajah, sedangkan yang lemah akan menjadi pecundang dan terus terjajah (Putra, 2018).

\section{Pursuit of Wealth}

Pengembangan industri pertahanan dan alutsista oleh berbagai negara tidak terlepas dari adanya harapan negara tersebut memperoleh keuntungan-keuntungan eknomi. Keuntungankeuntungan ekonomi yang diharapkan oleh negara adalah terjadinya pertumbuhan ekonomi, membuka peluang ekspor serta mendorong terjadinya industrialisasi (Bitzinger, 2015). Hal-hal ini lah yang disebut sebagai pursuit of wealth. Pengembangan medium battle tank Harimau oleh Indonesia tidak luput dari pertimbangan pursuit of wealth ini. Pemerintah Indonesia berharap dengan melakukan pengembangan industri pertahanan, salah satunya medium battle tank, akan dapat memberikan keuntungankeuntungan ekonomi bagi Indonesia.
Harapan bahwa dengan kemampuan industri pertahanan menciptakan persenjataan yang berkualitas dan canggih akan mendorong pembangunan ekonomi Indonesia secara keseluruhan dapat ditemukan dalam narasi pemangku jabatan dalam berbagai kesempatan. Ketua Dewan Perwakilan Rakyat (DPR) periode 2014 - 2019, Bambang Soesatyo menyatakan bahwa industri pertahanan Indonesia wajib untuk terus dikembangkan karena akan mendorong pertumbuhan ekonomi Indonesia (Lubabah, 2018). Pernyataan serupa juga disampaikan oleh Menteri Pertahanan Indonesia periode 2014-2019 (Hakim, 2018). Menurut kedua pejabat Indonesia tersebut keberadaan industri pertahanan yang kuat di Indonesia akan meningkatkan nilai tambah ekonomi Indonesia. Setidaknya terdapat dua aspek ekonomi yang akan terbantu oleh kehadiran industri pertahanan yang kuat, yakni aspek tenaga kerja dan neraca perdagangan. Industri pertahanan yang kuat dan mampu memproduksi alutsista canggih tidak hanya akan menyerap tenaga kerja, namun juga mendorong penitngkatan kualitas tenaga kerja Indonesia (Lubabah, 2018). Aspek kedua adalah terbukanya peluang ekspor bagi Indonesia dengan menjual produk-produk industri pertahannya ke luar negeri (Hakim, 2018).

Keyakinan bahwa dengan melakukan pengembangan industri pertahanan khususnya medium battle tank Harimau akan meningkatkan peluang ekspor Indonesia sangatlah beralasan. Hal ini jika merujuk pada pengalaman Indonesia mengekspor persenjataan yang telah berhasil diproduksi sebelumnya. Sebagai contohnya adalah produk PT. Pindad lainnya yakni panser Anoa yang telah digunakan oleh berbagai negara serta pasukan penjaga perdamaian 
PBB (Fikri, 2019; Media Indonesia, 2019). Panser Anoa yang pertama kali diperkenalkan kepada publik pada tahun 2006 merupakan salah satu alutsista andalan ekspor Indonesia. Berbagai negara telah membeli panser Anoa ini. Malaysia hingga saat ini telah memiliki 32 panser Anoa melalui pengadaan senilai kurang lebih 80 juta dollar Amerika Serikat (AS), meskipun sempat bermasalah dengan protes dari Renault selaku produsen mesin panser Anoa yang juga menawarkan panser ke Malaysia (Kumparan, 2018; Tempo.co, 2014). Brunei Darussalam juga merupakan negara yang memutuskan untuk membeli panser Anoa sebanyak 45 unit pada tahun 2018 (Kumparan, 2018; Permana, 2018).

Jika merujuk pada data yang dihimpun oleh Badan Pusat Statistik (BPS) dan dirilis katadata, nilai ekspor kendaraan tempur (Ranpur) dan bagian penunjang Ranpur Indonesia mengalami kenaikan sangat signfikan pada rentang tahun 2010 - 2018. Pada tahun 2010 nilai ekspor Indonesia sebesar 60 Juta Dollar AS. Nilai ekspor ini setiap tahunnya mengalami peningkatan, bahkan pada tahun 2018 nilai ekspor Indonesia sudah mencapai 1.1 Milyar Dollar AS. Penurunan nilai ekspor hanya terjadi pada tahun 2013, dengan nilai 110.1 Juta Dollar AS dibandingkan ekspor tahun 2012 yang mencapai 254 Juta Dollar AS. Gambar 1 menunjukkan kenaikan nilai ekspor Indonesia dalam komoditas Ranpur dan komponennya.

Selayaknya penjualan Ranpur maupun Alutsista Indonesia yang seperti yang disebutkan sebelumnya, medium battle tank Harimau juga memiliki masa depan yang cerah. Meskipun medium battle tank Harimau baru lulus sertifikasi pada tahun 2018 yang lalu, pada saat ini berbagai negara telah menyatakan ketertarikannya untuk mengakuisisi mesin tempur buatan Pindad. Negara-negara yang telah menyatakan ketertarikannya di antaranya adalah Filipina, Bangladesh, Brunei Darussalam dan Malaysia (ABC, 2019; Pindad, 2019; Kompas.com, 2018). Salah satu negara di Asia Selatan dikabarkan telah menyatakan ketertarikannya untuk membeli

Gambar 1

Grafik Nilai Ekspor Kendaran Tempur dan Komponennya

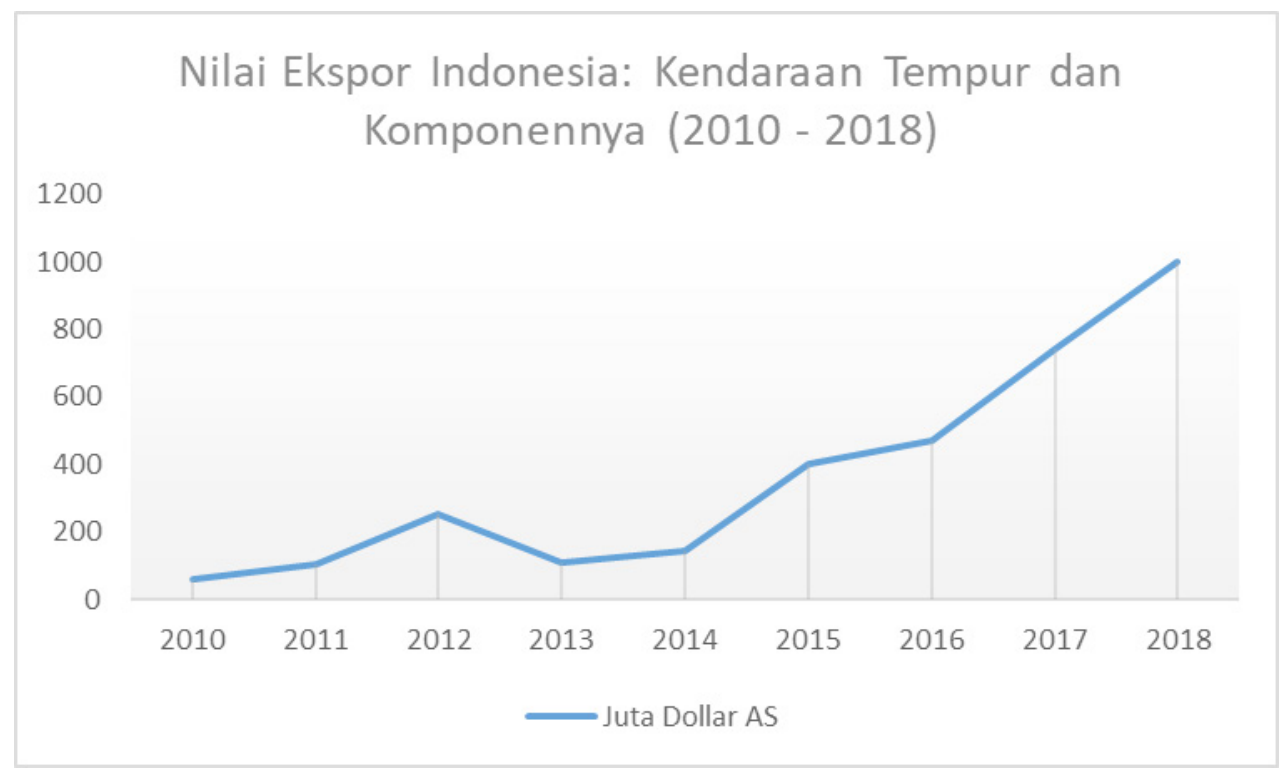

Sumber: Kusnandar, 2019 
120 unit medium battle tank Harimau (Antara, 2019; Gideon, 2019). Filipina bahkan telah menandatangani MoU pengadaan alutsista hasil produksi Indonesia, terutama medium battle tank Harimau pada bulan February 2020 (Handoyo, 2020; Kementerian BUMN, 2020).

\section{Pursuit of Prestige}

Berbagai negara saat ini mencoba membangun kapasitas industri pertahanan dalam negerinya. Negara-negara tersebut berharap dengan kemampuan industri pertahanannya memiliki dan mengembangkan sistem persenjataan berteknologi tinggi maka posisi mereka akan naik menjadi negaara besar atau dihormati. Hal ini sesuai dengan konsep techno-nationalist impulse yang diutarakan Bitzinger bahwa negara-negara Asia tetap menghendaki penguasaan teknologi persenjataan karena kemajuan industri pertahanan dapat menyebabkan prestise atau posisi negara tersebut meroket. Alasan pursuit of prestige ini juga menjadi salah satu alasan Indonesia memilih berkomitmen dalam pengembangan medium battle tank, meskipun tidak sesuai dengan proyeksi ancaman Indonesia maupun posisi Turki yang juga bukan negara produsen senjata utama dunia.

Medium battle tank Harimau yang dikembangkan oleh PT. Pindad diharapkan akan memberikan efek terhadap posisi Indonesia di dalam sistem internasional. Indonesia berharap melalui pengembangan ini Indonesia akan dipandang sebagai negara yang memiliki tingkat penguasaan teknologi tinggi. Selain itu keberadaan medium battle tank Harimau juga diharapkan mendorong posisi Indonesia mengingat tidak semua negara mampu menguasai pengembangan alutsista sekelasnya. Hal ini tentunya sangat beralasan mengingat jika merujuk kepada UNROCA battle tank merupakan salah satu bagian dari major conventional arms system (UNROCA, n.d.). Posisi battle tank setara dengan pesawat tempur, kapal perang maupun artileri dengan kaliber besar (UNROCA, n.d.). Oleh karena itu ketika suatu negara berhasil menguasai kemampuan memproduksi battle tank maka negara tersebut akan memperoleh predikat negara dengan industri pertahanan yang maju dan kuat dengan penguasaan teknologi tinggi.

Untuk memastikan apakah pengembangan medium battle tank Harimau oleh Indonesia dapat mendorong posisi dan prestige Indonesia didalam sistem intermasinal maka terdapat satu hal yang diperlukan. Hal tersebut adalah dengan melihat fakta di lapangan, apakah ada negara-negara di Asia Tenggara yang telah mampu memproduksi battle tank. Selain itu dalam ruang lingkup yang lebih luas, diperlukan juga data empiris mengenai negara-negara di dunia yang telah berhasil memproduksi battle tank. Adapun spesifikasi battle tank yang dimaksud adalah sesuai dengan standar atau penjelasan dari kategorisasi UNROCA. Tabel 1 menampilkan daftar negara-negara di dunia yang telah mampu memproduksi battle tank.

Merujuk pada tabel 1 tersebut, maka dapat diketahui bahwasanya hingga saat ini terdapat 22 negara yang mampu memproduksi battle tank selain Indonesia. Adapun dari 22 negara tersebut 9 di antaranya berada di Asia. Namun dari 9 negara produsen battle tank di Asia, tidak satupun yang berasal dari Asia Tenggara. Keberhasilan Indonesia memproduksi medium battle tank Harimau yang pengembangannya dimulai dari proses desain awal tentunya akan mampu meningkatkan posisi dan prestise Indonesia. Indonesia secara resmi menjadi satu-satunya 
Tabel 1

Daftar Negara Produsen Tank Dan Model Pengembangan Tank

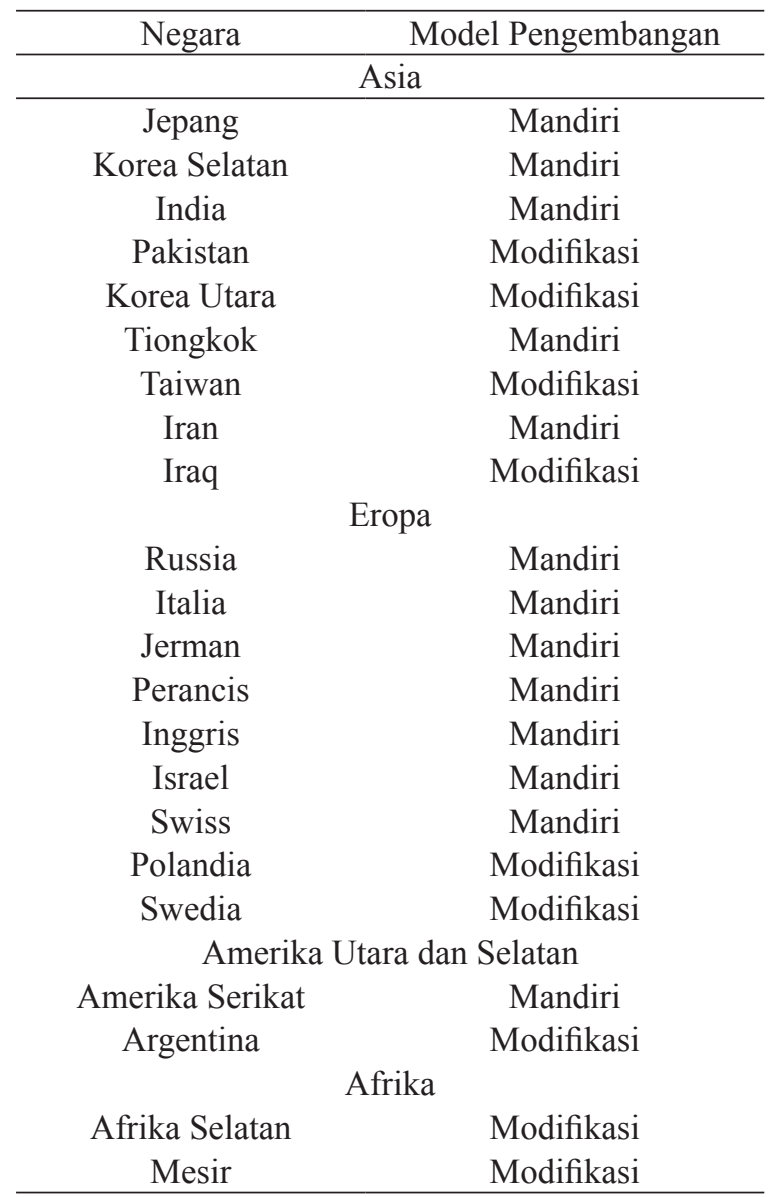

Sumber: Military Factory, 2020

negara di Asia Tenggara yang memiliki kemampuan memproduksi medium battle tank secara mandiri. Selain itu, keberhasilan ini juga menempatkan Indonesia bersama dengan 5 negara Asia lain yaitu Tiongkok, Jepang, Korea Selatan, Iran dan India, yang mampu mengembangkan battle tank secara mandiri atau bukan hanya memodifikasi atau mendapatkan lisensi battle tank yang sudah ada sebelumnya.

Selain meningkatkan prestise di dalam dunia internasional, keberhasilan pengembangan medium battle tank turut meningkatkan prestise di dalam negeri. Keberhasilan suatu negara menciptakan industri pertahanan yang kuat bisa dipergunakan oleh pemimpin atau partai politik berkuasa untuk meningkatkan posisi dan prestisenya (Bağc1 dan Kurç, 2017). Dalam konteks Indonesia hal ini juga dapat terlihat ketika proses pemilihan presiden pada tahun 2019. Ketika itu Presiden Joko Widodo menggunakan keberhasilan industri pertahanan Indonesia memproduksi kapal selam dan medium battle tank Harimau sebagai materi dalam debat calon presiden (Kusuma, 2019). Presiden Joko Widodo ketika itu membanggakan keberhasilan industri pertahanan Indonesia setelah pesaingnya yakni Prabowo Subianto, seorang purnawirawan jenderal, mengkritisi kondisi pertahanan dan anggaran Kementerian Pertahanan Indonesia (Nurmayanti, 2019).

Selain itu Presiden Joko Widodo semenjak awal dilantik menjadi Presiden pada tahun 2014 juga telah menekankan pada impiannya membentuk Indonesia yang mandiri. Kemandirian ini juga diinginkan oleh Presiden Joko Widodo terwujud dalam bidang pertahanan. Presiden Joko Widodo bahkan menekankan bahwa kemandirian pertahanan merupakan satu dari empat prioritas pemerintahannya di sektor pertahanan (Amenia, 2014; Angriani, 2014). Presiden Joko Widodo maupun pejabat pemerintahannya berulang kali menyampaikan bahwasanya pembelian alutsista TNI wajib mengutamakan produk dalam negeri (Indrawan, 2017; Stefanie, 2016; Wantimpres, 2016). Oleh karena itu pengembangan medium battle tank Harimau ini merupakan salah satu upaya pembuktian janji Presiden Joko Widodo.

Direktur Jenderal Potensi Pertahanan (Pothan) Kementerian Pertahanan, Bondan Tiara Sofyan juga menyampaikan statement terkait keberhasilan Indonesia mengembangkan medium battle tank Harimau. Keberhasilan 
Indonesia mengembangkan medium battle tank merupakan sebuah pembuktian bahwa Indonesia memiliki kemampuan memproduksi persenjataan berat sekelas tank (Parno, 2018). Hal serupa juga turut disampaikan oleh Tim Pertahanan Kedeputian V Kantor Staf Presiden. Pengembangan medium battle tank Harimau merupakan pembuktian bahwa Indonesia mampu berinovasi menghasilkan produk teknologi tinggi yang berguna untuk mencapai cita-cita kemandirian pertahanan dan mengawal kedaulatan Indonesia (Kantor Staf Presiden, 2018).

\section{SIMPULAN}

Berdasar penjelasan tersebut di atas dapat ditarik simpulan sebagai berikut.

Pertama, keputusan Indonesia untuk melakukan pengembangan medium battle tank Harimau bersama Turki merupakan upaya untuk meningkatkan ketahanan alutsista TNI, khususnya TNI AD. Berkaca melalui data empirik bahwa ketahanan alutsista yang dimiliki TNI tidak dalam keadaan yang memadai mengingat sudah berusia uzur dan secara teknologi, kehadiran medium battle tank Harimau akan mampu memperbaiki ketahanan alutsista TNI. Medium battle tank Harimau memberi dampak terhadap kekuatan alutsista TNI serta keamanan logistik pertahanan.

Kedua, medium battle tank Harimau juga berpotensi menjadi alutsista yang diekspor ke negara lain serta meningkatkan prestise Indonesia karena Indonesia menajdi satu dari sedikit negara di dunia yang mampu mengembangkan medium battle tank. Keberhasilan ini juga dimanfaatkan Pemerintah Indonesia untuk meningkatkan kredibilitas dan popularitasnya di dalam negeri.

Selanjutnya, direkomendasikan hal sebagai berikut.
Pertama, penelitian lebih lanjut masih sangat diperlukan untuk semakin memperkaya analisis terhadap kasus ini. Hal ini juga dikarenakan pada penelitian ini peneliti tidak membahas mengenai pengaruh dari pengembangan medium battle tank Harimau terhadap pembelian alutsista Indonesia yang berasal dari negara lain.

\section{DAFTAR PUSTAKA}

ABC, 2019, Alasan Impor Alat Militer Indonesia Turun, Saat Saudi dan Australia Malah Naik. Diakses dari Tempo.co: <https://www.tempo.co/ abc/4782/alasan-impor-alat-militerindonesia-turun-saat-saudi-danaustralia-malah-naik>, pada 15 Februari 2020.

Al-fadhat, F., dan NNA. Effendi, 2019, 'Kerjasama Pertahanan IndonesiaKorea Selatan: Kedaulatan Maritim dan Transfer Teknologi dalam Pengadaan Kapal Selam DSME 209/1400', Jurnal Ketahanan Nasional, Vol. 25, No. 3, hh. 373-392.

Amrullah, M. R., 2016, 'Diplomasi Pertahanan Indonesia Terhadap Turki: Studi Kasus Kerjasama Industri Pertahanan', Jurnal Pertahanan \& Bela Negara, Vol. 6, No. 1, hh. 151-168.

Amenia, R., 2014 , Jokowi Minta Kemandirian Industri Pertahanan. Diakses dari CNN Indonesia: $<$ https://www.cnnindonesia.com/ nasional/20141230115236-20-21296/ jokowi-minta-kemandirian-industripertahanan>, pada 15 Februari 2020.

Anggi, K., dan A. Resty, 2016, Kisah Embargo AS dan Sukhoi Rusia di Balik Jet Tempur $R I$. Diakses dari CNN Indonesia: $<$ https://www.cnnindonesia.com/ 
nasional/20160301150059-20-114600/ kisah-embargo-as-dan-sukhoi-rusia-dibalik-jet-tempur-ri>, pada 15 Februari 2020.

Angriani, D., 2014, Prioritas Utama Pertahanan RI Era Jokowi. Diakses dari Medcom: <https://www.medcom. $\mathrm{id} /$ nasional/hukum/Gbm4QOyN-4prioritas-utama-pertahanan-ri-erajokowi $>$ pada 10 Maret 2020.

Antara, 2019, PT Pindad Jajaki Ekspor 120 Unit Tank Harimau ke Asia Selatan. Diakses dari Tempo.co: $<$ https://bisnis. tempo.co/read/1195091/pt-pindadjajaki-ekspor-120-unit-tank-harimauke-asia-selatan $/$ full\&view $=$ ok $>$, pada 16 April 2020.

Armandha, S. T., A. Datumaya, dan W. Sumari, 2015, 'Ekonomi Politik Kerja Sama Korea Selatan - Indonesia dalam Joint Development Pesawat Tempur KFX / IFX', Global \& Strategis, Vol. 10, No. 1, hh. 74-94.

Armor Specs, 2020, STANAG 4569 / AEP-55. Diakses dari: $<$ https://www.armorspecs. com/stanag-4569/> pada 16 April 2020.

Badan Riset dan Inovasi Nasional, 2016, Mockup Modern Medium Weight Tank di \#IndoDefence2016 Diakses dari: <https://risbang.ristekbrin.go.id/ publikasi/berita-kegiatan/mockupmodern-medium-weight-tank-diindodefence2016/>, pada 10 Juni 2020.

Bağc1, H. dan C.Kurç, 2017, 'Turkey's strategic choice: buy or make weapons?', Defence Studies. Routledge, Vol. 17, No. 1, hh. 38-62.

Ball, S. J., 2010, 'The Macmillan Government, British Arms Exports and Indonesia', Contemporary British History, Vol. 16, No. 2, hh. 77-98.
Bitzinger, R. A., 2003, Towards a Brave New Arms Industry. London: Routledge.

Bitzinger, R. A., 2010, 'A New Arms Race? Explaining Recent Southeast Asian Military Acquisitions', Contemporary Southeast Asia, Vol. 32, No. 1, hh. 50-69.

Bitzinger, R. A., 2011, 'Offsets and defense industrialization in Indonesia and Singapore', in In Arms trade and economic development: Theory, policy, and cases in arms trade offsets., hh. 249-263.

Bitzinger, R. A., 2013 , 'Revisiting armaments production in Southeast Asia: New dreams, same challenges', Contemporary Southeast Asia, Vol. 35, No. 3, hh. 369-394.

Bitzinger, R. A., 2015, 'Defense Industries in Asia and the Technonationalist Impulse', Contemporary Security Policy, Vol. 36, No. 3, hh. 453-472.

Collin, K. S. L., 2015, 'What next for the indonesian navy? Challenges and prospects for attaining the minimum essential force by 2024', Contemporary Southeast Asia, Vol. 37, No. 3, hh. 432-462.

Dzikri, I., 2016, 'Negara dan Kapasitas Adopsi Inovasi: Studi Kasus Tranformasi Pertahanan Indonesia Periode 1998-2014', Global: Jurnal Politik Internasional, Vol.18, No. 2, hh. 131-151.

Edgerton, D. E. H., 2007, 'The Contradictions of Techno-Nationalism and TechnoGlobalism: A Historical Perspective', New Global Studies, Vol. 1, No. 1.

Fikri, A., 2018, Pindad Klaim Kandungan Lokal Medium Tank Tembus 70\%. Diakses dari Tempo.co: <https://bisnis. tempo.co/read/1117731/pindad-klaim- 
kandungan-lokal-medium-tank-tembus70-persen>pada 17 Maret 2020.

Fikri, A., 2019, Hebat! PBB Pakai 350 Panser Anoa Buatan Pindad. Diakses dari Tempo.co: <https://bisnis.tempo. co/read/1193015/hebat-pbb-pakai350-panser-anoa-buatan-pindad/ full\&view=ok>, pada 16 April 2020.

Firmansyah, T., 2018, Wakil Dubes AS: Embargo Militer Indonesia Adalah Masa Lalu. Diakses dari: <https:// www.republika.co.id/berita/nasional/ umum/18/05/16/p8tcmd377-wakildubes-as-embargo-militer-indonesiaadalah-masa-lalu>, pada 10 Juni 2020.

FNSS, 2018, Kaplan MT.

FNSS, 2019, Pulat Integration Shows Kaplan Ability to Adapt to Evolivng Threats. Diakses dari FNSS: <https: //www. fnss.com.tr/en/news/pulat-integrationshows-kaplan-mts-ability-to-adapt-toevolving-threats $>$, pada 28 Maret 2020.

Gideon, A., 2019, Dua Negara Asia Bakal Beli 164 Tank Harimau Buatan Pindad. Diakses dari Liputan6.com: $<$ https: //www.liputan6.com/bisnis/ $\mathrm{read} / 3940290 / 2$-negara-di-asia-bakalbeli-164-tank-harimau-buatan-pindad >, pada 19 April 2020.

Hakim, S., 2018, Kemajuan Industri Pertahanan Akan Ikut Dorong Kemandirian Ekonomi. Diakses dari Antara: <https:// www.antaranews.com/berita/677048/ kemajuan-industri-pertahanan-akanikut-dorong-kemandirian-ekonomi >, pada 14 April 2020.

Handoyo, A. Z., 2020, Filipina Beli Medium Tank dan Senjata Produksi PT. Pindad. Diakses dari RRI.co.id: < http://rri.co.id/ post/berita/793865/nasional/filipina_ beli_medium_tank_dan_senjata_ produksi_pt_pindad_indonesia html $>$, pada 17 April 2020.

Hughes, C. W., 2011, The slow death of Japanese techno-nationalism? emerging comparative lessons for China's defense production', Journal of Strategic Studies, Vol.34, No.3, hh. 451-479.

Ikhsanudin, A., 2018, Penampakan Tank Harimau Buatan Pindad yang Lincah dan Akurat Menembak. Diakses dari Detik.com: <https://news.detik.com/ berita/d-4291276/penampakan-tankharimau-buatan-pindad-yang-lincahakurat-menembak>, pada 22 Maret 2020.

Indrawan,A., 2017, Menhan Setuju Pengadaan Alutsista Utamakan Produk Dalam Negeri. Diakses dari Merdeka.com: $<$ https://www.merdeka.com/peristiwa/ menhan-setuju-pengadaan-alutsistautamakan-produk-dalam-negeri.html>, pada 3 April 2020.

Kantor Staf Presiden, 2018, KSP Apresiasi Kekuatan Industri Pertahanan Indonesia. Diakses dari:<http://ksp. go.id/ksp-apresiasi-kekuatan-industripertahanan-indonesia/>, pada 1 Juni 2020.

Kementerian BUMN, 2020, Dirut Pindad Saksikan Penandatanganan MoU Logistik dan Indhan RI - Philipina. Diakses dari Kementerian BUMN: $<$ http://www.bumn.go.id/pindad/ berita/1 -Dirut-Pindad-SaksikanPenandatanganan-MoU-Logistik-danIndhan-RI-Philipina>

Kementerian Pertahanan, 2008, Buku Putih Pertahanan Indonesia. Jakarta: Kementerian Pertahanan Indonesia. 
Kementerian Pertahanan, 2014, Buku Putih Pertahanan Indonesia. Jakarta: Kementerian Pertahanan Indonesia.

Kementerian Pertahanan, 2015, Buku Putih Pertahanan Indonesia. Jakarta: Kementerian Pertahanan Indonesia.

Kementerian Pertahanan, 2018, Menhan Malaysia Disebut Tertatik Medium Tank Pindad. Diakses dari Kompas. com: <https://nasional.kompas.com/ $\mathrm{read} / 2018 / 11 / 08 / 22233861 /$ menhanmalaysia-disebut-tertarik-medium-tankpindad $>$, pada 11 April 2020.

Kompas.com., 2018, Saat Medium Tank Pindad Susuri Medan tersulit di Indonesia. Diakses dari Kompas. com: <https://regional.kompas.com/ $\mathrm{read} / 2018 / 08 / 12 / 09341011 / \mathrm{saat}-$ medium-tank-pindad-susuri-medantersulit-di-indonesia? page $=$ all $>$, pada 20 Maret 2020.

Krause, K., 1991, 'Military Statecraft: Power and Influence in Soviet and American Arms Transfer Relationships', International Studies Quarterly, Vol. 35, No. 3, h. 313.

Kumparan, 2018, Mengenal Tank Anoa dan Senjata Serbu SS2-V2 yang Dibeli Sultan Brunei. Diakses dari Kumparan: $<$ https://kumparan.com/kumparannews/ mengenal-tank-anoa-dan-senjata-serbuss2-v2-yang-dibeli-sultan-brunei>, pada 11 April 2020.

Kusnandar, V. B., 2019, Berapa Nilai Ekspor Kendaraan Tempur Indonesia. Diakses dari Katadata: <https://databoks. katadata.co.id/datapublish/2019/11/13/ berapa-nilai-ekspor-kendaraan-tempurindonesia>, pada 8 April 2020.

Kusuma, H., 2019, Ini Tank dan Kapal Selam yang Dibanggakan Jokowi Saat Debat.
Diakses dari Detik.com: $<$ https://finance. detik.com/industri/d-4491185/ini-tankdan-kapal-selam-yang-dibanggakanjokowi-saat-debat>, pada 25 April 2020.

Lie, J. dan R.J.Samuels,1995, "Rich Nation, Strong Army": National Security and the Technological Transformation of Japan.', Pacific Affairs, h. 598.

Lubabah, R. G., 2018, Tingkatkan Nilai Tambah Indonesia DPR Dorong Industri Perhanan Dikembangkan. Diakses dari Merdeka. com: $<$ https://www.merdeka.com/politik/ tingkatkan-nilai-tambah-indonesiadpr-dorong-industri-pertahanandikembangkan.html $>$, pada 13 April 2020.

Luerdi dan H. Marisa, 2018, 'Civil Participation in Military Innovation : Cooperation between the Defense Industry of Indonesia and Turkey 20102018 Partisipasi Sipil dalam Inovasi Militer : Kerjasama Industri Pertahanan Indonesia dan Turki 2010-2018', Global Strategis, Vol. 13, No. 2, hh. 17-34.

Matanasi, P., 2018, Kavaleri Angkatan Darat Bermodal Warisan Belanda. Diakses dari Tirto.id: <https://tirto.id/kavaleriangkatan-darat-bermodal-warisanbelanda-cEtf $>$, pada 20 Februari 2020.

Mearsheimer, J. J., 2001, The Tragedy of Great Power Politics, W.W. Norton \& Company.

Media Indonesia, 2019, Panser Anoa PT. Pindad Mulai Mendunia. Diakses dari Media Indonesia: <https://mediaindonesia. $\mathrm{com} / \mathrm{read} /$ detail/228409-panser-anoapt-pindad-mulai-mendunia $>$, pada 15 Maret 2020

Military Factory, 2020, Main Battle Tanks. Diakses dari Military Factory: $<$ https:// www.militaryfactory.com/armor/mainbattle-tanks>.asp, pada 18 April 2020 
Febry Triantama -- Kerjasama Pengembangan Medium Battle Tank Harimau Sebagai Perwujudan Ketahanan Alutsista Tentara Nasional Indonesia

Mutakin, J., 2017, Menhan Sebut Tank Medium Buatan Pindad Cocok di Indonesia . Diakses dari Medcom.id: <https://m. medcom.id/nasional/daerah/1bV6oB1bmenhan-sebut-tank-medium-buatanpindad-cocok-di-indonesia>, pada 19 Maret 2020

Neuman, S. G., 2010, 'Power, influence, and hierarchy: Defense industries in a unipolar world', Defence and Peace Economics, Vol. 21, 1, hh. 105-134.

Nurmayanti, 2019, Prabowo Kritisi Kondisi Alutsista Jokowi Pamer Tank dan Kapal Selam Buatan RI. Diakses dari Liputan6. com: <https://www.liputan6.com/bisnis/ $\mathrm{read} / 3930155 /$ prabowo-kritisi-kondisialutsista-jokowi-pamer-tank-dan-kapalselam-buatan-ri>, pada 3 April, 2020.

Parno, 2018, Pembuktian Indonesia Mampu Produksi Medium Tank. Diakses dari: $<$ https://jabarprov.go.id/index.php/ news/29594/2018/08/28/BondanPembuktian-Indonesia-MampuProduksi-Medium-Tank\#> pada 1 Juni 2020.

Permana, E., 2018, Brunei Pesan 45 Panser Anoa. Diakses dari Anadolu Agency: $<$ https://www.aa.com.tr/id/headlinehari/pindad-brunei-pesan-45-panseranoa/1136045>, pada 11 April 2020.

Pindad, 2016, Pindad dan FNSS Luncurkan Desain Medium Tank di Indo Defence 2016. Diakses dar: <http://www.bumn. go.id/pindad/berita/0-Pindad-danFNSS-Luncurkan-Desain-MediumTank-di-Indo-Defence-2016>, pada 10 Juni 2020.

Pindad, 2016, Pindad Luncurkan Sanca dan Desain Medium Tank di Indo Defence 2016. Diakses dari: < https:// www.pindad.com/pindad-luncurkan- sanca-dan-desain-medium-tank-diindo-defence-2016>, pada 10 Juni 2020.

Pindad, 2017, Medium Tank Diperkenalkan Pada HUT TNI Ke-72 di Cilegon. Diakses dari: <http://www.bumn. go.id/pindad/berita/1-Medium-TankDiperkenalkan-Pada-HUT-TNI-KE-72Di-Cilegon>, pada 10 Juni 2020.

Pindad, 2018, Pindad Rampungkan Sertifikasi Medium Tank. Diakses dari: <https:// www.pindad.com/pindad-rampungkansertifikasi-medium-tank $>$, pada 10 Juni 2020.

Pindad, 2019, Sambut KSAD Bangladesh Dirtekbang Pindad Pamerkan Medium Tank. Diakses dari Pindad: <https:// www.pindad.com/sambut-ksadbangladesh-dirtekbangpindad-pamerkan-medium-tank $>$, pada 10 April 2020.

Pindad, 2020, Pindad Resmikan Lini Baru Fasilitas Produksi Sistem Senjata. Diakses dari Pindad: < https://pindad. com/pindad-resmikan-lini-barufasilitas-produksi-sistem-senjata $>$, pada 30 Maret 2020.

Prasetyo, T. dan D.A.Salim, 2017, 'Evaluasi Kinerja KKIP Dalam Kerjasama Republik Indonesia-Korea Selatan Pada Pembangunan Kapal Selam Untuk Mendukung Ketahanan Alutsista TNI Angkatan Laut', Jurnal Ketahanan Nasional, Vol. 23, No. 1, hh. 86-103.

Putra, E. P., 2018, Menhan Ryamirzard Tinjau Turret di PT. Pindad. Diakses dari: $<$ https://nasional.republika.co.id/berita/ nasional/umum/17/09/18/owh78k430menhan-ryamizard-tinjau-turret-di-ptpindad,> 1 Juni 2020.

Rahmat, R., dan S.Cranny-Evans, 2019, Indonesia Signs LoI With PT. Pindad 
for Kaplan Medium Tanks. Diakses dari IHS Jane's: <https:/www.janes.com/ article/87994/indonesia-signs-loi-withpt-pindad-for-kaplan-medium-tanks>, pada 18 Februari 2020.

Ramadhan, D. I., 2018, Tank Medium Buatan Pindad Kebal Kena Ledakan TNT. Diakses dari Detik.com: <https://news. detik.com/berita/d-4112307/tankmedium-buatan-pindad-kebal-kenaledakan-tnt>, pada 22 Maret 2020.

Raymond, G. V., 2017, 'Naval modernization in Southeast Asia: Under the shadow of army dominance?', Contemporary Southeast Asia, Vol. 39, No. 1, hh. 149-177.

Reich, Robert B., 1987, The Rise of Technonationalism, Atlantic Montly

Rosh, R. M., 1990, 'Third World Arms Production a, No. dthe Evolving Interstate System', Journal of Conflict Resolution, Vol. 34, No. 1, hh. 57-73.

Salsabiela, B. F., 2016, 'Analisis Akuisisi Teknologi Industri Pertahanan Indonesia : Studi Kasus Pengembangan Pesawat Tempur Korean Fighter Xperiment / Indonesian Fighter Xperiment ( Kfx / Ifx) Analysis Of Technology Acquisitions Of Indonesian Defense Industry: A Case Study Of', Jurnal Pertahanan, Vol. 6, No. 2, hh. 51-74.

Santosa, I. (n.d.). Armada TNI AL. Diakses dari Kompas Interaktif: <https://interaktif. kompas.id/baca/armada-tni-al $>$, pada 24 Februari 2020.

Siddiq, T., 2018, Mengenal Harimau Tank Medium Terbaru Buatan Pindad. Diakses dari Tempo.co: $<$ https://nasional. tempo. co/read/1144649/mengenal-harimautank-medium-terbaru-buatan-pindad/ full\&view=ok>, pada 16 Februari 2020 .
Stefani, C., 2014, Indonesia-Turki Kerjasama Kembangkan Tank Bersama. Diakses dari CNN Indonesia: $<$ https: //www.cnnindonesia.com/ nasional/20141107173556-26-10332/ indonesia-turki-kembangkan-tankbersama?>, pada 24 Februari 2020.

Stefanie, C., 2016, Presiden Utamakan Penggunaan Alutsista Produk Dalam Negeri. Diakses dari CNN Indonesia: $<$ https:// www.cnnindonesia.com/ nasional/20160721111929-20-146075/ presiden-utamakan-penggunaanalutsista-produk-dalam-neger $>$, pada 14 April 2020

Sudarmanto, A. dan H.Sudibyakto, 2011, 'Implementasi Kebijakan Pengadaan Alutsista Untuk Mendukung Kebutuhan Operasional Tentara Nasional Indonesia', Jurnal Ketahanan Nasional, Vol. 16, No. 2, hh. 29-45.

Sugiyono, 2009, Metode Penelitian Bisnis (Pendekatan Kuantitatif, Kualitatif, dan $R \& D$, Bandung: Alfabeta.

Taufik, M., 2013, Perpustakaan Lemhanas. Diakses dari Perpustakaan Lemhanas: $<$ http://lib.lemhannas.go.id/public/ media/catalog/0010011600000000134/ swf $/ 3767 /$ mobile/index.html\#p=1>, pada 27 Mei 2020 .

Tempo.co., 2014, TNI AL Terkuat di Masa Soekarno. Diakses dari Tempo: $<$ https:// nasional.tempo.co/read/628140/tni-alterkuat-di-asia-di-masa-sukarno $>$, pada 26 Februari 2020.

Tempo.co., 2014, Indonesia Turki Sepakati Produksi Tank Medium. Diakses dari Tempo.co: <ttps://nasional.tempo.co/ $\mathrm{read} / 620487 /$ indonesia-turki-sepakatiproduksi-tank-medium/full\&view=ok $>$, pada 26 Februari 2020. 
Tempo.co., 2014, Renalut Protes Ekspor Anoa ke Malaysia Tersendat. Diakses dari Tempo.co: <https://bisnis.tempo. co/read/568313/renault-protes-eksporanoa-ke-malaysia-tersendat $>$, pada 20 Maret 2020.

Tyroler-Cooper, S. dan A. Peet, 2011, 'The Chinese aviation industry: Technohybrid patterns of development in the C919 program', Journal of Strategic Studies, Vol. 34, No. 3, hh. 383-404.

Undang-Undang Republik Indonesia No. 16 Tahun 2012 Tentang Industri Pertahanan UNROCA, (n.d.), United Nations Register of Conventional Arms. Diakses dari UNROCA: <https://www.unroca.org/ categories>, pada 21 April 2020.

Wantimpres, 2016, Kunjungan Kerja Wantimpres Bidang Pertahanan
Keamanan ke Jawa Barat. Diakses dari Dewan Pertimbangan Presideen: $<$ http:// wantimpres.go.id/? $p=1140$ \&lang=id $>$, pada 21 April 2020.

Wiezeman, S. T., 2019, Arms Flows to Southeast Asia. Stockholm: SIPRI.

Wulandari, A., 2017, 'Kepentingan Indonesia Bekerjasama Dengan Turki Dalam Industri Pertahanan (Studi Kasus: Pembuatan Tank Medium)', Jurnal Online Mahasiswa FISIP UNRI, Vol 4, No. 2, hh. 1-12.

Yildirim, G., 2017, New Tank to Debut at Turkish Defense Fair. Diakses dari Anadolou Agency: <https://www. aa.com.tr/en/economy/new-tank-todebut-at-turkish defensefair/814856>, pada10 Juni 2020. 